\title{
Phylogenetic insight into subgenera Idaeobatus and Malachobatus (Rubus, Rosaceae) inferring from ISH analysis
}

\author{
Yan Wang ${ }^{1}$, Xiaorong Wang ${ }^{1,2^{*}}$, Qing Chen ${ }^{1}$, Li Zhang ${ }^{1}$, Haoru Tang ${ }^{1}$, Ya Luo ${ }^{1}$ and Zejing Liu ${ }^{1}$
}

\begin{abstract}
Background: Rubus is a large and taxonomically complex genus exhibiting agamospermy, polyploidy and frequent hybridization. The objective of this work was to elucidate rDNA disrtibution pattern and investigate genomic composition of polyploids in 16 Rubus taxa $(2 n=2 x, 3 x, 4 x, 8 x)$ of two subgenera /daeobatus and Malachobatus by ISH method.

Results: The basic Rubus genome had one $45 \mathrm{~S}$ rDNA locus, and all the polyploids (except $R$. setchuenensis) had the expected multiples of this number. Diploid and tetraploid Rubus taxa carried two 55 rDNA, whereas the triploid and octoploid species only had three. The duplicated $45 \mathrm{~S}$ rDNA sites tended to be conserved, whereas those of $5 \mathrm{~S}$ rDNA tended to be eliminated after polyploidization. The accession R03-20 was an autotriploid $R$. parvifolius, while R03-27 and R03-57 were naturally-occurred triploid hybrids between R. parvifolius and R. coreanus. GISH results suggested that $R$. parvifolius had close relationship with polyploids from Malachobatus.

Conclusions: The polyploids from Malachobatus were probable allopolyploid. In addition, Rubus parvifolius might be involved in hybridization, polyploidization and speciation of some Idaeobatus and Malachobatus species.
\end{abstract}

Keywords: Rubus, Allopolyploid, Hybrid, rDNA-FISH, GISH

\section{Background}

Rubus Linnaeus (Rosaceae) has long been deemed taxonomically challenging due to its propensity for agamospermy, polyploidy and frequent hybridization [1]. This genus is divided into 12 subgenera, with numerous infrageneric sections and series [2-4], containing several hundreds of sexual species to perhaps thousands of apomictic microspecies [5-7]. China, exceptionally rich in Rubus species, especially the south-western part of the country, was proposed to be a major centre of diversity for the genus, with about 200 species [8]. Most species here are mainly concentrated in two subgenera (or sections by $\mathrm{Lu}$ and Yü et al.), Idaeobatus and Malachobatus, estimated as much as 83 and 84 species, respectively, containing 24 sections $[9,10]$. Subgenus Idaeobatus species are predominantly diploid, whereas subg. Malachobatus represents a polyploid

\footnotetext{
* Correspondence: wangxrtj@163.com

${ }^{1}$ College of Horticulture, Sichuan Agricultural University, Ya'an 625014 People's Republic of China

${ }^{2}$ Institute of Pomology and Olericulture, Sichuan Agricultural University, Chengdu 611130, People's Republic of China
}

complex, with tetraploidy, hexaploidy, octoploidy or tetradecaploidy level $[6,11,12]$. Interestingly, $R$. parvifolius in subg. Idaeobatus had various ploidy levels, with di-, tri-, tetraploid, and mixed diploid-tetraploid [13]. Not only are the phylogenetic relationships between these species unknown, we also don't even know to what extent ploidy level varies among them.

Evolutionary process in the genus Rubus has been argued for a long time. Based on data from morphology and chromosome counts, Lu [8] suggested that evolution in Rubus proceeded from woody to herbaceous plants, and from compound to simple leaves. If Lu's morphological hypothesis [8] was correct, then species in subg. Idaeobatus might be the most primitive with woody plant and compound leaf, and members of subg. Malachobatus were more advanced with simple-leaved species. However, molecular phylogenetic evidence from ITS markers did not seem to support this hypothesis [14]. Recently, Alice et al. [15], with ITS, rpl16, and trn $\mathrm{L} / \mathrm{F}$ sequences, proposed the possibility that subg. Malachobatus was originated from subg. Idaeobatus 
diploid species but failed to seek out these ancestors in his study. In addition, previous studies using both ITS and cpDNA ( $n d h \mathrm{~F}, r p l 16$ and $\operatorname{trn} \mathrm{L} / \mathrm{F}$ ) sequences from Bhutanese, Korean, and Pacific Rubus indicated that the subg. Idaeobatus was a polyphyletic group, forming at least two distinct groups $[14,16,17]$, implying that subg. Idaeobatus might be relative primitive in the genus Rubus. In comparative studies on karyotype of 28 taxa from subg. Idaeobatus and Malachobatus, eighteen taxa from 7 sections of subg. Idaeobatus showed diverse chromosome morphology both between and within sections, while species belonging to 6 sections of subg. Malachobatus exhibited uniform intra-sectional karyotypic features but different karyotypes between sections. As a result, we inferred that species of subg. Idaeobatus with abundant genetic variation were of more complex taxon than those of Malachobatus [12]. These facts indicated that some particular subg. Idaeobatus species, being involved in hybridization, polyploidization and speciation of Rubus, might play an important role in phylogeny of the genus. It has been reported that some Idaeobatus species can hybridize each other freely and produce fertile offspring, e.g., $R$. parvifolius with $R$. coreanus and $R$. sieboldii; $R$. trifidus with $R$. hirsutus, $R$. microphyllus and $R$. palmatus [18-23].

Rubus parvifolius and $R$. coreanus, are two widely distributed species of subg. Idaeobatus in China [10,24]. In our field investigation, $R$. parvifolius displays remarkable morphological diversity in traits such as leaf size, prickle density, fruit size, and seed number. There are also some differences in the color of canes and prickles, most of which were reddish brown but a few were green. Moreover, $R$. parvifolius exhibited not only abundant molecular variation, but also various ploidy levels and conspicuous different karyotypes (with $2 x, 3 x, 4 x$, and cytotype mixture of $2 x$ and $4 x$ ), whereas another widely-distributed species $R$. coreanus revealed typical morphology and highly uniform ploidy $(2 x)$ and karyotype [13]. Interestingly, both two species often grow sympatrically with those species from both Idaeobatus and Malachobatus. It has been reported that $R$. parvifolius could facilitate natural hybridization and formations of natural hybrids with $R$. coreanus $(R . \times$ hiraseanus, $2 x$ and $3 x$ ) and $R$. phoenicolasius $(R . \times$ nikaii, $2 x$ ) from Idaeobatus [18,22,23], and R. seiboldii ( $R . \times$ tawadanus, $3 x)$ from Malachobatus $[19,21]$. There has not any report that $R$. coreanus could hybridize with other Rubus species other than $R$. parvifolius yet. Therefore, we speculated that $R$. parvifolius might play an important role in speciation and phylogeny in both subgenera Idaeobatus and Malachobatus in Rubus genus.

In situ hybridization techniques are effective tools for phylogenetic inference and hybrid identification in plant research. Fluorescence in situ hybridization (FISH) has been used for physical mapping of repetitive DNA sequences and multi-copy families [25,26]. It is possible to determine the genomic homology between species and identify chromosome composition of hybrids by genomic in situ hybridization (GISH) [25,27]. Previous studies on cytogenetics on Rubus were mostly limited to chromosome counting $[6,11,19,20,28-31]$ or traditional karyotype analysis $[12,13,18,21-23,32,33]$. FISH with $45 \mathrm{~S}$ rDNA was established in $R$. parvifolius [34] and callus lines from European and American countries [35]. Screening power of GISH in identifying interspecies hybrids of raspberry and blackberry had already been demonstrated [36,37]. These molecular techniques were expected to be applied to phylogenetic analysis among other Rubus species.

In this study, we tried to obtain new phylogenetic insight into the subgenera Idaeobatus and Malachobatus of Rubus, and seek for any clues to infer the speculated role of $R$. parvifolius in speciation and polyploidization processes of the genus. Physical distribution patterns of 45S and 5S rDNA in 18 accessions, including 14 Rubus taxa $(2 n=2 x, 4 x, 8 x)$ and 3 resembling $R$. parvifolius accessions $(2 n=3 x)$, from 9 out of 24 sections belonging to the two subgenera were analyzed by FISH. Comparative GISH analysis on these taxa probed with $R$. parvifolius DNA (as $R$. coreanus a comparison) was conducted. In addition, three triploid accessions: R03-20 (recently collected), R03-27 [38] and R03-57 (recently collected) were included here to identify their genomic composition. All these results will shed light on the phylogenetic history of the genus Rubus.

\section{Results}

Number and localization of $45 \mathrm{~S}$ and $5 \mathrm{~S}$ rDNA sites

In either diploid or polyploid species, $45 \mathrm{~S}$ rDNA sites localized at the terminal regions, and 5S rDNA sites were localized on proximal or sub-terminal region of the short arms (Figures 1 and 2, Table 1). Nine diploid taxa exhibited two $45 \mathrm{~S}$ and two $5 \mathrm{~S}$ rDNA sites, despite variable signal intensity (Figures 1 and 2A-I), in congruent with their diploid levels. A pair of satellites was detected along with two strong $45 \mathrm{~S}$ rDNA sites in both $R$. niveus (R01-1) and R. corchorifolius (R01-6) (Figures 1 and 2A and I). The three taxa, R. ellipticus (R01-7), R. ellipticus var. obcordatus (R01-2), and R. pinfaensis (R01-22), had two $45 \mathrm{~S}$ rDNA sites on terminal chromosomal regions of chromosome 3. 5S rDNA sites localized on the proximal region of short arms of chromosome 5 in R. ellipticus and $R$. pinfaensis, but existed at sub-terminal regions of chromosome 5 in $R$. ellipticus var. obcordatus (Figures 1 and 2B,C and E). There was an identical 45S and $5 \mathrm{~S}$ rDNA distribution of chromosome 3 and 6 in $R$. parvifolius (R03-5) and $R$. coreanus (R03-6) (Figures 1 and $2 \mathrm{D}$ and G) from Xichong county. In contrast, $R$. coreanus (R01-4) from Ya'an city had two 45S rDNA sites 


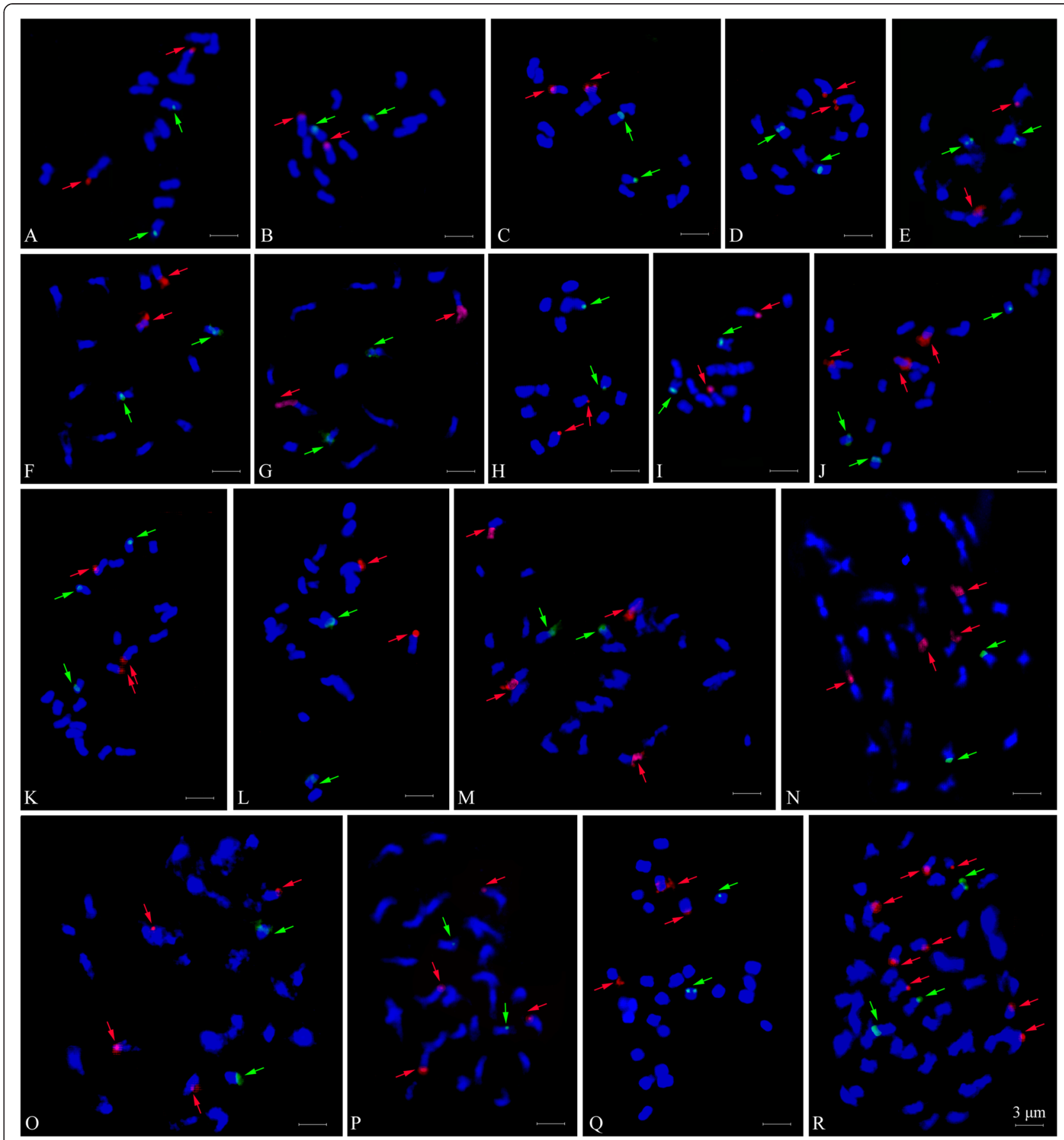

Figure 1 Numbers of 45S (red) and 5S rDNA (green) sites visualized by FISH in eighteen accessions from subgenera Idaeobatus and Malachobatus of the genus Rubus. A: R. niveus; B: R. ellipticus; C: R. ellipticus var. obcordatus; D: R. parvifolius; E: R. pinfaensis; F: R. coreanus (R01-4); G: R. coreanus (R03-6); H: R. tsangii; I: R. corchorifolius; J: R03-20; K: R03-27; L: R03-57; $\mathbf{M}: R$. lambertianus var. glaber; $\mathbf{N}: R$. parkeri; $\mathbf{O}: R$. assamensis; $\mathbf{P}: R$. multibracteanus; Q: R. setchuenensis; R: R. buergeri.

distributing on the satellites of chromosome 7 and two $5 \mathrm{~S}$ rDNA sites at the proximal region of the short arm on chromosome 6 (Figures 1 and 2F).

As for the three triploid accessions, three hybridization signals with the same intensity were detected using both $45 \mathrm{~S}$ and 5S rDNA probes in R03-20 (Figures 1 and 2J).
Accession R03-27 exhibited three 45S and three 5S rDNA sites, with one $5 \mathrm{~S}$ rDNA signal was much larger and more intensive than the other two (Figures 1 and $2 \mathrm{~K}$ ). However, only two $45 \mathrm{~S}$ and two $5 \mathrm{~S}$ rDNA sites were found in R0357 , both signals the same intensity, locating on the chromosome 3 and 6, respectively (Figures 1 and 2L). 


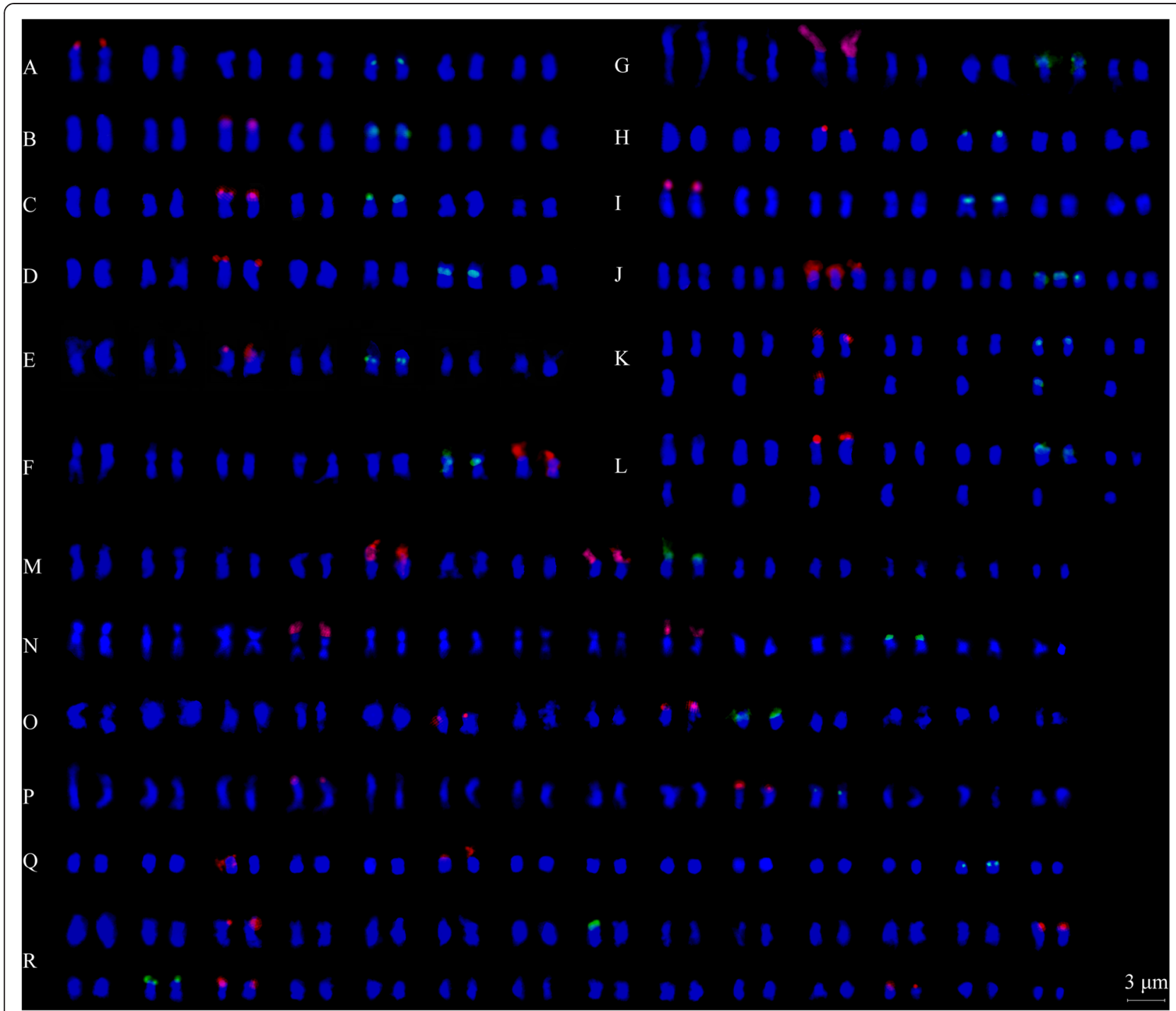

Figure 2 Karyotype of eighteen Rubus accessions revealed by FISH. A: R. niveus; B: R. ellipticus; C: R. ellipticus var. obcordatus; D: R. parvifolius; E: R. pinfaensis; F: R. coreanus (R01-4); G: R. coreanus (R03-6); H: R. tsangii; I: R. corchorifolius; J: R03-20; K: R03-27; L: R03-57; M: R. lambertianus var. glaber; N: R. parkeri; O: R. assamensis; P: R. multibracteanus; Q: R. setchuenensis; R: R. buergeri.

The four tetraploid taxa, R. lambertianus var. glaber (R01-8), R. parkeri (R01-12), R. assamensis (R01-10), and $R$. multibracteatus (R01-23), shared the same number of rDNA sites, four for $45 \mathrm{~S}$ rDNA and two for $5 \mathrm{~S}$ rDNA sites (Figures 1 and $2 \mathrm{M}-\mathrm{P}$ ). The number of $45 \mathrm{~S}$ rDNA was twice to that detected in diploids. Although the number and the position of rDNA sites were strictly consistent among the tetraploids, variations in signal size and intensity among sites were observed. For instance, two $45 \mathrm{~S}$ rDNA loci presented remarkably higher levels of signal intensity than the rest in the four species (Figures 1 and 2M-P). However, only three 45S rDNA signals were detected in $R$. setchuenensis (R01-24), one signal being significantly larger than the other two (Figures 1 and 2Q). Two 5S rDNA sites showed equal intensities on a pair of chromosomes in five tetraploids (Figures 1 and 2M-Q).

In octoploid $R$. buergeri (R01-11) (Figures 1 and 2R), eight $45 \mathrm{~S}$ rDNA sites were detected, among which, two were markedly bigger than the others. Only three $5 \mathrm{~S}$ rDNA sites were found in $R$. buergeri, much less than the number we anticipated based on comparison with the diploids.

GISH analysis of fourteen accessions from Idaeobatus and Malachobatus probed with $R$. parvifolius

It was obvious that at $\sim 85 \%$ stringency, the parvifolius (R03-5; $2 x$ ) DNA probe generated a large number of signals dispersedly distributed through six to fourteen chromosomes in all diploid species (Figures 3 and 4A-D, F-I). 
Table 1 Numbers of $45 S$ and 5S rDNA sites and GISH signals on chromosomes of these accessions tested in Rubus

\begin{tabular}{|c|c|c|c|c|c|c|c|c|}
\hline \multirow[t]{2}{*}{ Taxa } & \multirow{2}{*}{\multicolumn{2}{|c|}{$2 n$ Locality }} & \multirow[t]{2}{*}{ Voucher } & \multicolumn{3}{|c|}{$\begin{array}{l}\text { rDNA loci number and } \\
\text { distribution }\end{array}$} & \multicolumn{2}{|c|}{$\begin{array}{l}\text { GISH signals on chromosomes probed with } R \text {. } \\
\text { parvifolius }(R 03-5,2 x)\end{array}$} \\
\hline & & & & $45 S$ & $5 S$ & $\begin{array}{l}\text { Figures } 1 \\
\text { and } 2\end{array}$ & Number and Localization & $\begin{array}{l}\text { Figures } 3 \\
\text { and } 4\end{array}$ \\
\hline
\end{tabular}

\section{Subg. Idaeobatus Focke}

Sect. Idaeanthi (Focke) Yü \& Lu

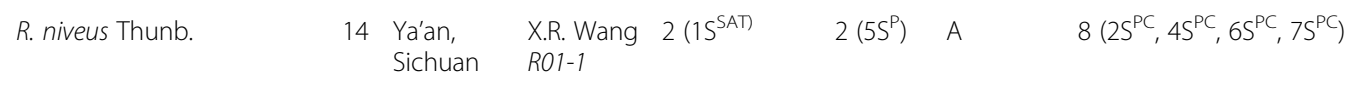

Sect. Stimulantes Yü \& Lu

R. ellipticus Smith
R. ellipticus Smith var.
obcordatus (Franch.) Focke

R. parvifolius $\mathrm{L}$.


14 Ya'an, X.R. Wang $2\left(3 S^{\top}\right)$ Sichuan R01-7

$\begin{array}{lll}2\left(5 S^{P}\right) & B & 14 \text { (Dispersed through chromosomes) } \\ 2\left(5 S^{S T}\right) \quad C & 14\left(3 S^{T}, 1-2 S^{P C}, 4-7 S^{P C}\right) \\ 2\left(6 S^{P}\right) \quad D & 14\left(3 S^{T}, 1-2 S^{P C}, 4-7 S^{P C}\right)\end{array}$

\begin{tabular}{|c|c|c|c|c|c|c|c|}
\hline R. pinfaensis Lévl. Et Vant. & 14 & $\begin{array}{l}\text { Ya'an, } \\
\text { Sichuan }\end{array}$ & $\begin{array}{l}\text { X.R. Wang } \\
\text { R01-22 }\end{array}$ & $2\left(3 S^{\top}\right)$ & $2\left(5 S^{P}\right)$ & $\mathrm{E}$ & 14 (Dispersed through chromosomes) \\
\hline \multirow[t]{2}{*}{ R. coreanus Miq. } & 14 & $\begin{array}{l}\text { Ya'an, } \\
\text { Sichuan }\end{array}$ & $\begin{array}{l}\text { X.R. Wang } \\
\text { R01-4 }\end{array}$ & $2\left(7 S^{S A T}\right)$ & $2\left(6 S^{P}\right)$ & $\mathrm{F}$ & - \\
\hline & 14 & $\begin{array}{l}\text { Xichong, } \\
\text { Sichuan }\end{array}$ & $\begin{array}{l}\text { X.R. Wang } \\
\text { R03-6 }\end{array}$ & $2\left(3 S^{S A T}\right)$ & $2\left(6 S^{P}\right)$ & G & $14\left(3 S^{\top}, 1-7 S^{P C}\right)$ \\
\hline
\end{tabular}

Sect. Pungentes (Focke) Yü \& Lu

Sect. Rosaefolii (Focke) Yü \& Lu

$$
\begin{array}{llll}
\text { R. tsangii Merr. } & 14 \begin{array}{l}
\text { Ya'an, } \\
\text { Sichuan }
\end{array} & \begin{array}{l}
\text { X.R. Wang } \\
\text { R01-21 }
\end{array} & 2\left(3 S^{\top}\right)
\end{array}
$$

\begin{tabular}{|c|c|c|c|c|}
\hline 14 & $\begin{array}{l}\text { Ya'an, } \\
\text { Sichuan }\end{array}$ & $\begin{array}{l}\text { X.R. Wang } \\
\text { R01-6 }\end{array}$ & $2\left(1 S^{S A T}\right)$ & $2\left(5 S^{P}\right)$ \\
\hline 21 & $\begin{array}{l}\text { Xichong, } \\
\text { Sichuan }\end{array}$ & $\begin{array}{l}\text { X.R. Wang } \\
\text { R03-20 }\end{array}$ & $3\left(3 S^{\top}\right)$ & $3\left(6 S^{P}\right)$ \\
\hline 2 & $\begin{array}{l}\text { Xichong, } \\
\text { Sichuan }\end{array}$ & $\begin{array}{l}\text { X.R. Wang } \\
\text { R03-27 }\end{array}$ & $3\left(3 S^{\top}\right)$ & $3\left(6 S^{P}\right)$ \\
\hline 21 & $\begin{array}{l}\text { Xichong, } \\
\text { Sichuan }\end{array}$ & $\begin{array}{l}\text { X.R. Wang } \\
\text { R03-57 }\end{array}$ & $2\left(3 S^{\top}\right)$ & $2\left(6 S^{P}\right)$ \\
\hline
\end{tabular}$$
2\left(5 S^{S T}\right) \quad H
$$$$
8\left(1 S^{\top}, 3 S^{\top}, 4 S^{\top}, 6 S^{\top}\right)
$$

Sect. Corchorifolii (Focke) Yü \& Lu

$$
\text { R. corchorifolius L. f. }
$$

\section{Subg. Malachobatus Focke}

Sect. Acuminati (Focke) Yü \& Lu

$$
\text { R. lambertianus Ser. var. }
$$
glaber Hemsl.

28 Ya'an Sichuan

X.R. Wang $4\left(5 S^{\top}, 8 S^{\top}\right) \quad 2\left(9 S^{S T}\right) \quad M$ RO1-8
28 Ya'an, Sichuan

X.R. Wang $4\left(4 S^{\top}, 9 S^{\top}\right)$

R01-12

28 Ya'an, Sichuan

X.R. Wang $4\left(6 S^{\top}, 9 S^{\top}\right) \quad 2\left(10 S^{P}\right) \quad 0$ R01-10

ect. Dolichophylli Yü \& Lu

$$
\text { R. parkeri Hance }
$$

Sect. Elongati (Focke) Yü \& Lu

$$
\text { R. assamensis Focke }
$$

Sect. Moluceani (Focke) Yü \& Lu

R. multibracteatus Lévl. Et
Vant.
R. setchuenensis Bureau et
Franch.
R. buergeri Miq.

$$
\begin{aligned}
& 28 \text { Ya'an, } \\
& \text { Sichuan } \\
& \text { X.R. Wang } 4\left(4 S^{\top}, 10 S^{\top}\right) \quad 2 \quad P \\
& \text { R01-23 }\left(11 S^{S T}\right) \\
& 28 \text { Ya'an, X.R. Wang } 3\left(3 S^{\top}, 6 S^{\top}\right) \quad 2\left(13 S^{P}\right) \quad Q \\
& \text { Sichuan R01-24 } \\
& 56 \text { Ya'an, X.R. Wang } 8\left(3 S^{\top}, 14 S^{\top}, 3\left(8 S^{S T}, \quad R\right.\right. \\
& \text { Sichuan }
\end{aligned}
$$

6 (Dispersed through chromosomes
$2,4$ and 5$)$
$21\left(15\right.$ in $S^{P C}, 6$ dispersed through
chromosomes)
-




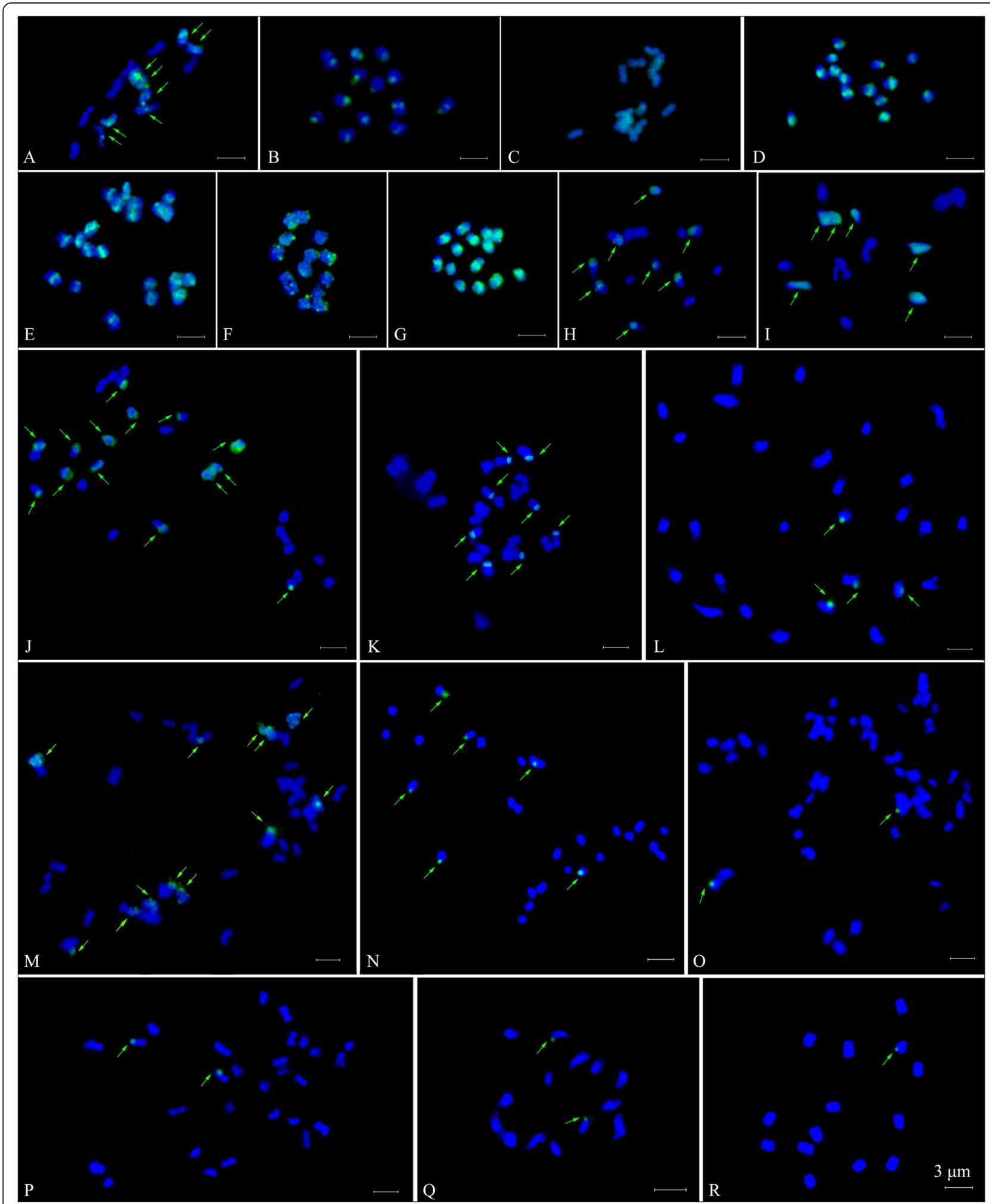

Figure $3 \mathrm{GISH}$ signal patterns on chromosomes of fifteen Rubus accessions (A-O) from subgenera Idaeobatus and Malachobatus probed by R. parvifolius (R03-5; 2x) DNA. A: R. niveus; B: R. ellipticus; C: R. ellipticus var. obcordatus; D: R. parvifolius; E: R03-20; F: R. pinfaensis; G: R. coreanus (R03-6); H: R. tsangii; I: R. corchorifolius; J: R. lambertianus var. glaber; K: R. parkeri; L: R. assamensis; $\mathbf{M}: R$. multibracteatus; N: $R$. setchuenensis; O: R. buergeri. P: GISH signals in $R$. assamensis (R01-10, 4x) probed with $R$. coreanus (R03-6, 2x). Q-R: GISH results in $R$. parvifolius $(R 03-5,2 x)$ and $R$. coreanus $(R 03-6,2 x)$ probed by $R$. assamensis $(R 01-10,4 x)$, respectively. 


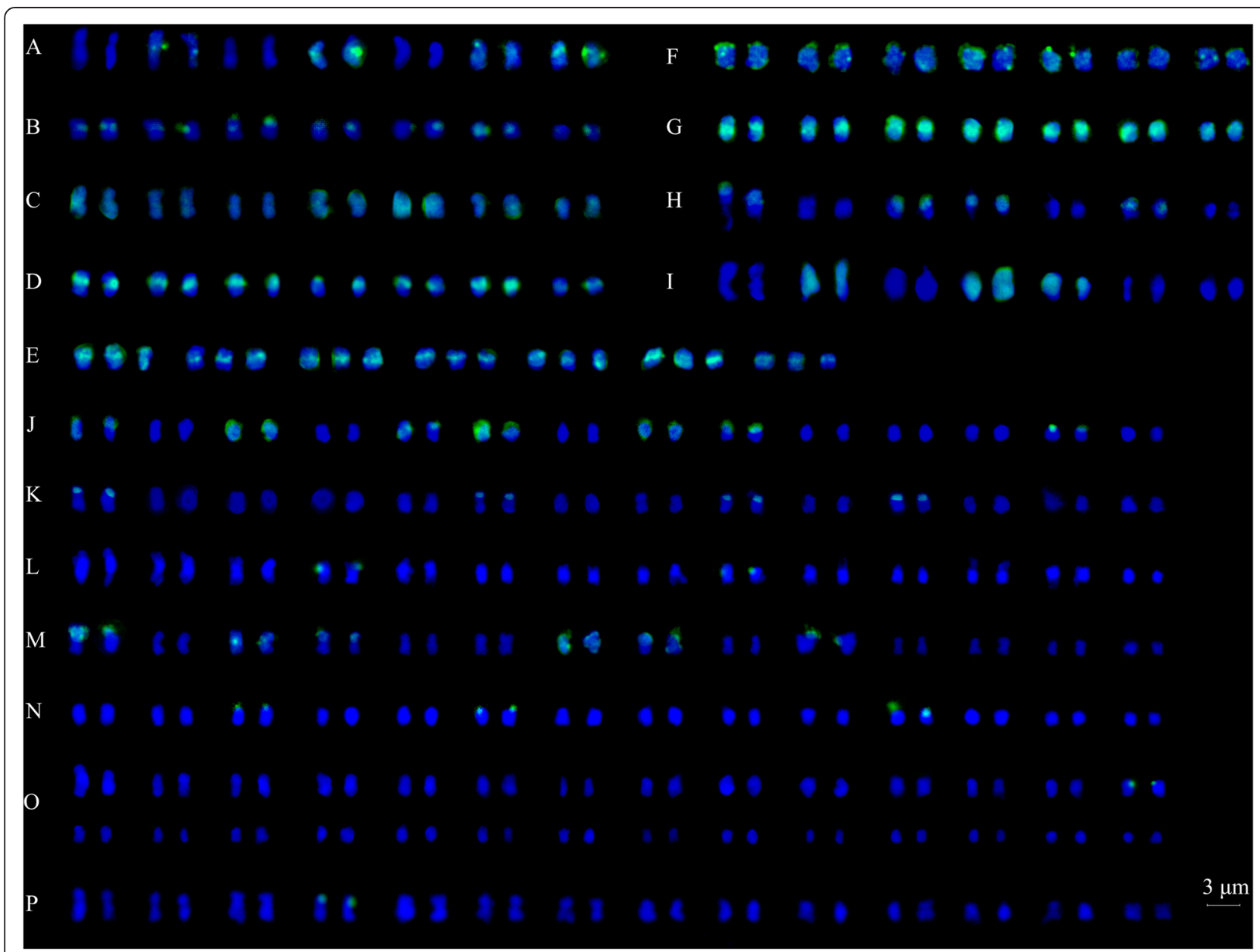

Figure 4 Karyotype of fifteen Rubus accessions (A-O) revealed by GISH analysis probed by DNA of R. parvifolius (R03-5; 2x). A: R. niveuS; B: R. ellipticus; C: R. ellipticus var. obcordatus; D: R. parvifolius (R03-5); E: R03-20; $\mathbf{F}: R$. pinfaensis; $\mathbf{G}$ : $R$. coreanus; $\mathbf{H}: R$. tsangii; I: $R$. corchorifolius; J: $R$. lambertianus var. glaber; K: R. parkeri; L: R. assamensis; $\mathbf{M}: R$. multibracteatus; $\mathbf{N}: R$. setchuenensis; O: R. buergeri. $\mathbf{P}$ : GISH signals in $R$. assamensis $(R 01-10,4 x)$ probed with $R$. coreanus $(R 03-6,2 x)$.

The all chromosomes of R03-20 (3x) and $R$. coreanus (R03-6) displayed the strongest signal intensity at the centromeric and terminal regions (Figures 3 and $4 \mathrm{E}$ and $G$ ). This was similar to the signal pattern of selfGISH in R. parvifolius (Figures 3 and 4D). GISH results also revealed that fourteen chromosomes of $R$. ellipticus (R01-7), R. ellipticus var. obcordatus (R01-2) and R. pinfaensis (R01-22) were weakly labelled at the same regions (Figures 3 and $4 \mathrm{~B}, \mathrm{C}$ and $\mathrm{F}$ ). The hybridization signals were detected at the same regions on eight chromosomes of $R$. niveus (R01-1) and $R$. tsangii (R01-21) (Figures 3 and $4 \mathrm{~A}$ and $\mathrm{H}$ ). The remaining species, $R$. corchorifolius (R01-6) exhibited weak signals at the centromeric or telomeric region on six chromosomes (Figures 3 and 4I).

Among the five tetraploids, fourteen chromosomes of $R$. lambertianus var. glaber (R01-8) were labelled with genomic DNA of $R$. parvifolius, eight at the telomeric regions, four through along the chromosomes, and two at the centromeric parts (Figures 3 and 4J). Eight and twelve chromosomes were labelled clearly at telomeric and centromeric regions of $R$. parkeri (R01-12) and $R$. multibracteatus (R01-23), respectively (Figures 3 and $4 \mathrm{~K}$ and $\mathrm{M})$. In $R$. assamensis (R01-10) and R. setchuenensis (R01-24), four and six signals were detected at the telomeric parts (Figures 3 and $4 \mathrm{~L}$ and N). Only two weak signals were detected at the telomeric regions in octoploid R. buergeri (R01-11) (Figures 3 and 4O).

When using probe from another widely distributed species $R$. coreanus (R03-6), only two signals were observed in tetraploid species (one taxon $R$. assamensis was shown in Figure 3P). Only two or one signal in $R$. parvifolius or $R$. coreanus was detected using genomic DNA of the polyploids as probes (only data for two representative taxa were shown here, in Figure $3 \mathrm{Q}$ and R). 


\section{GISH analysis of two triploids probed with $R$. parvifolius and $R$. coreanus}

Self-GISH in $R$. parvifolius, the pericentromeric regions of all mitotic chromosomes were strongly labelled, whereas other chromosomal regions were not (Figures 5 and 6A1). 21 chromosomes of R03-20 showed strong signals at centromeric parts when using probe of $R$. parvifolius and $50 \times$ excess blocking DNA of $R$. coreanus (R03-6) (Figures 5 and 6B1).

GISH also provided evidence for our hypothesis: the accession $R 03-27(2 n=3 x=21)$ is hybrid origination, from results discriminating parental chromosomes of $R$. parvifolius (R03-5) and $R$. coreanus (R03-6) (Figures 5 and $6 \mathrm{C}-\mathrm{E})$. Using genomic DNA of $R$. parvifolius in the presence of $50 \times$ excess unlabelled blocking DNA of $R$. coreanus, GISH revealed 21 hybridization signals in RO327. Fourteen chromosomes almost completely colored with green signals (Figures 5 and $6 \mathrm{C} 1$, arrows), while the remained seven had less signals at the centromeric region. When using $R$. coreanus DNA as a probe combined with 50× excess unlabelled blocking DNA of $R$. parvifolius, seven chromosomes were colored by dense signals in most areas (Figures 5 and 6C2, arrows), and the last three had signals in the telomeric regions. All 21 chromosomes of R03-27 showed strong hybridization signals at centromeric regions without blocking DNA (Figures 5 and 6D). When the ratio of blocking DNA to probe DNA got to 100:1, chromosomes from R03-27 did not give any signals (Figures 5 and $6 \mathrm{E}$ ). The GISH of another accession R03-57 also showed the similar results with that of R03-27 when using $R$. parvifolius and $R$. coreanus as probes (data not shown in Figures 5 and 6).

\section{Discussion}

Chromosomal patterns of 455 and 5S rDNA in Rubus

In diploid Rubus taxa, the observations of two $45 \mathrm{~S}$ rDNA and two 5S rDNA sites was generally consistent with previous findings in $R$. idaeus and $R$. parvifolius [34-37]. At the diploid level, one set of Rubus chromosome $(x=7)$ was typified by the presence of one terminal $45 \mathrm{~S}$ locus and one proximal $5 \mathrm{~S}$ locus on the short arm of different chromosomes. 45S rDNA sites localized on the short arm, which might represent the nucleolar organiser regions (NOR) [36,39]. In Rosaceae family, most of the diploid plants examined had two sites of both $45 \mathrm{~S}$ and 5S rDNA [40-42], and all rDNA exhibited a similar distribution pattern. That is, in general, $45 \mathrm{~S}$ rDNA repeats resided at the terminal regions, while $5 \mathrm{~S}$ rDNA sites distributed in interstitial and proximal regions of chromosomes. 5S rDNA sites were also detected at a telomeric (or sub-telomeric) position in some species, such as Sanguisorba annua [34], Fragaria $\times$ ananassa [43] and some Rubus taxa in this study. This might be a consequence of chromosome rearrangements [34].

In the three triploid accessions tested, R03-20 and R03-27 shared the same number of rDNA sites. But only two $45 \mathrm{~S}$ and $5 \mathrm{~S}$ rDNA loci were detected in R03-57. The presence of the expected number of $5 \mathrm{~S}$ sites in the former two might be explained by their recent origin. R03-57 showed obvious genetic differentiation from its

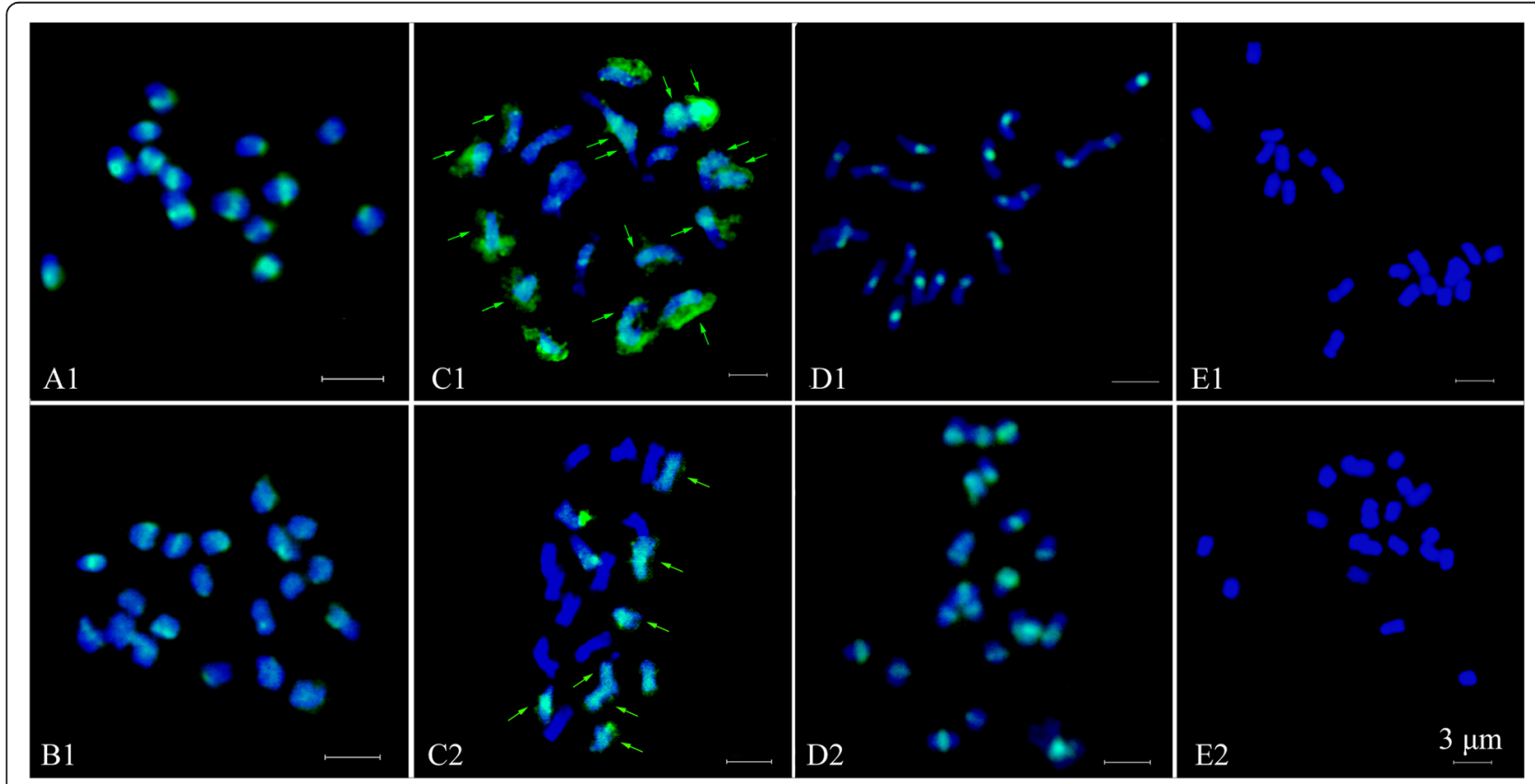

Figure 5 GISH results on chromosomes of R03-5 (2x, A1), R03-20 (3x, B1), and R03-27 (3x, C-E) probed by DNA from R. parvifolius (1: R03-5) and $R$. coreanus (2: R03-6). The ratio of blocking DNA to probe DNA was 50 (C), 0 (D), and 100 (E), respectively. 


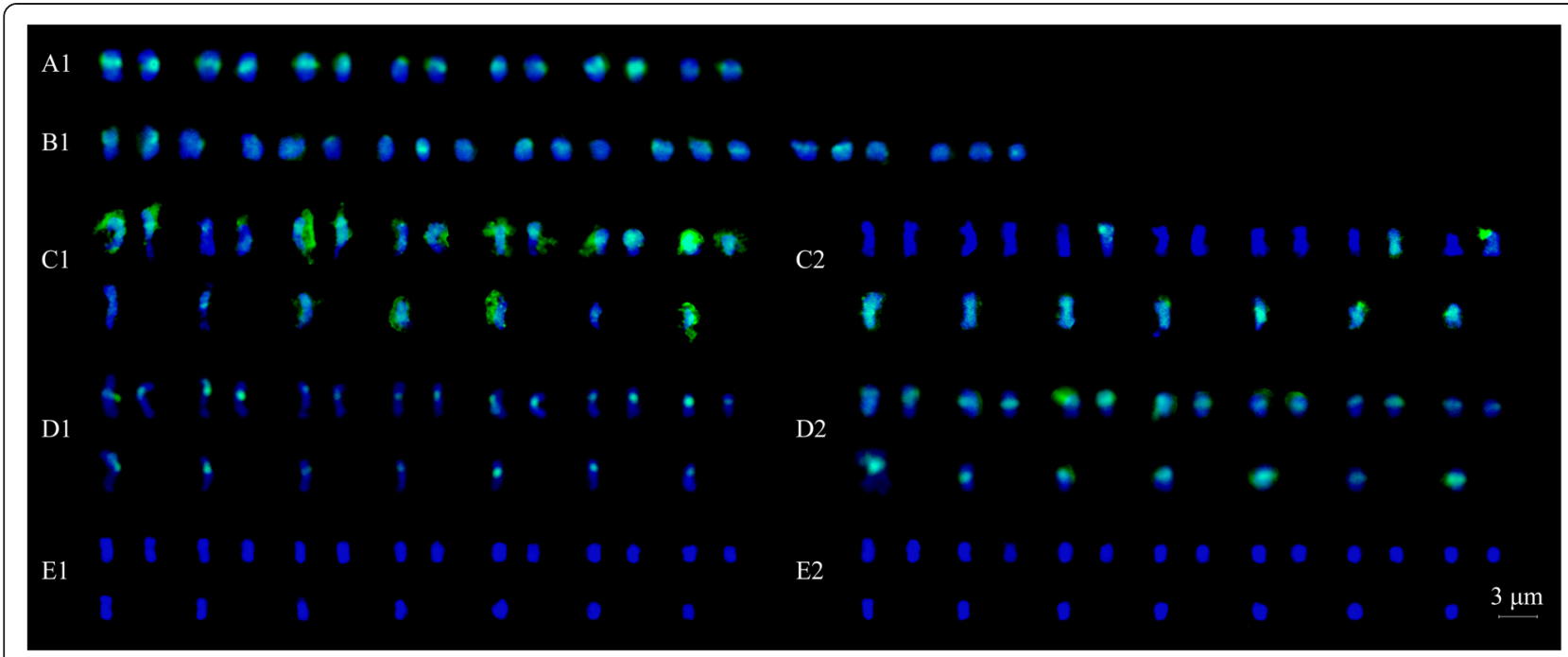

Figure 6 Karyotype of R03-5 (2x, A1), R03-20 (3x, B1), and R03-27 (3x, C-E) based on GISH results probed by DNA from R. parvifolius (1: R03-5) and $R$. coreanus (2: R03-6).

parents during its long evolutionary history, mainly involving chromosomal rearrangement or segment deletion or lost. Of course, other explanations might be reasonable too. It was believable that this site loss has arisen from an early event, as reported among octoploid Fragaria and subspecies [44]. The loss of $45 \mathrm{~S}$ rDNA might be related to nucleolar dominance [45] as well.

Among the six polyploids of subg. Malachobatus, multiples of $45 \mathrm{~S}$ rDNA site number were in proportion to the increasing ploidy level. In the octoploid $R$. buergeri (R01-11), there were four times of $45 \mathrm{~S}$ rDNA loci to that in diploids (Figures 1 and 2R). The site number in the tetraploids was twice as those in diploids (Figures 1 and 2M-P), except $R$. setchuenensis. Higher signal intensity was observed in $R$. setchuenensis (R01-24) on one chromosome represented existing of a longer rDNA coding sequence. This might be explaining the possible reason for loss of $45 \mathrm{~S}$ rDNA by simple translocation and recombination of chromosome segment where $45 \mathrm{~S}$ rDNA resides. Similar results were recorded in an aneuoctoploid cv 'Aurora' [37]. In contrast, the increasing number for $5 \mathrm{~S}$ rDNA loci was incongruent with the multiplied chromosome number (Figures 1 and 2M-R). For instance, two 5S rDNA sites were detected in both diploid and tetraploid species. In octoploid $R$. buergeri (R01-11), chromosome number counted twice of those in tetraploids, but only one additional $5 \mathrm{~S}$ locus was detected here when compared (Figures 1 and 2R). These results indicated that the duplicated sites of $45 \mathrm{~S} \mathrm{rDNA}$ tend to be conserved, whereas $5 \mathrm{~S}$ rDNA sites had a tendency toward elimination after polyploidization. This was in agreement with the study in Fragaria [44], Prunus [46], and Sanguisorba [34]. Thus, this tendency might be common in polyploids within Rosaceae.

\section{Origins of some polyploid Rubus taxa}

Polyploidy and hybridization are prevalent in Rubus [14]. Hybridization in Rubus occurs mostly between closely related species $[18,47]$. The Rubus hybrids' chromosome numbers increased due to fertilization of unreduced gametes from one or both of the parents [48]. Fertilization of unreduced gametes was also considered as a dominant process involving in the origin of polyploid plants by Bretagnolle and Thompson [49].

In this study, we observed the same number, size and distribution patterns of the $45 \mathrm{~S}$ and $5 \mathrm{~S}$ rDNA loci in each haploid complement of the diploid $R$. parvifolius (R03-5) and triploid R03-20 (Figure 2D and J). The R0320 also showed strong signals at the centromeric region on all chromosomes when using R03-5 DNA as probes (Figure 5B1). Based on the similarity of rDNA localization as well as in plant morphology but larger leaflet and fruit to the diploid $R$. parvifolius (R03-5), we believe the accession $R 03-20$ was an autotriploid $R$. parvifolius. It was likely that $R 03-20$ derived from fusion of an unreduced gamete $(2 n)$ and a reduced gamete $(n)$, both from the diploid.

Natural hybridization and introgression has been described as a fundamental evolutionary process of species complexes [50]. It has been reported that $R$. parvifolius and $R$. coreanus could form hybrids, naturally or artificially $[18,23]$. Together with GISH results, the accession R03-27 was most likely a natural hybrid between these two species, comprising of an unreduced gamete from $R$. parvifolius and a reduced gamete from $R$. coreanus. Moreover, there were weak hybridization signals in other parts of the chromosome centromere region of R03-27 (Figures 5 and $6 \mathrm{C}$ ), indicating the close relationship between its parents. It had also been described in hybrids 
of Begonia, and Diospyros species [51,52]. Another accession R03-57 was also a natural hybrid between $R$. parvifolius and $R$. coreanus.

Allopolyploids have long been recognized as an important mode of plant speciation [53], and it can be identified by $45 \mathrm{~S}$ rDNA signal number, as well as intensity [41]. Polymorphism of $45 \mathrm{~S}$ rDNA signal intensities among the polyploids might imply different repeat copy numbers among different rDNA sites [44]. As far as allopolyploid Rubus was concerned, Lim et al. [37] reported that one $45 \mathrm{~S}$ rDNA site was markedly bigger than the rest among the four 45S rDNA sites of the allotetraploid hybrid-berry (R'R'BB, raspberry $\times$ blackberry). Here, four (eight) $45 \mathrm{~S}$ rDNA sites localized on two (four) pairs of different chromosomes in tetraploids (octoploid), with two loci much stronger intensity (Figures 1 and $2 \mathrm{M}-\mathrm{R}$ ). The meiotic pairing of polyploids mostly formed bivalents: with $94 \%$ to $98 \%$ bivalents for tetraploids; $14.4 \%$ univalents, $83.2 \%$ bivalents, $0.86 \%$ trivalents, and $1.44 \%$ quadrivalents for octoploid R. buergeri [Nan et al. Studies on meiotic pairing behavior and rDNA distribution pattern in six Rubus taxa (Rosaceae), unpublished]. Therefore, we supported the presumption that the six polyploids, $R$. lambertianus var. glaber (R01-8), R. parkeri (R01-12), R. assamensis (R01-10), R. multibracteatus (R01-23), R. setchuenensis (R01-24), and R. buergeri (R01-11), were all of allopolyploidy origin. Moreover, based on the similar rDNA patterns, these tetraploid species probably shared common genomic composition, since they had a common ancestor as proposed by phylogenetic analysis based on different DNA sequences (Alice et al.) [15].

\section{Implication of R. parvifolius in speciation of the two subgenera}

The chromosomes were intensely and uniformly labelled with the probes from the same species in GISH analysis, whereas chromosomes were scantily and irregularly labelled with the probes from different species [54]. This could be expected because phylogenetically close species have many DNA sequences in common. Here in a series of GISH experiments, the chromosomes of $R$. coreanus (R03-6) hybridized with $R$. parvifolius (R03-5) generated the strongest signal intensity. This could be inferred that the genome of $R$. coreanus was most closely related to that of $R$. parvifolius among the species tested. Other taxa in subg. Idaeobatus, $R$. ellipticus (R01-7) and $R$. ellipticus var. obcordatus (R01-2) showed close relationship with $R$. parvifolius. It was noteworthy that $R$. pinfaensis (R01-22) was also close to $R$. parvifolius even though they were assigned to two different sections. The signal strength was varied among different taxa (Figures 3 and 4A-I), indicating the different repeat number of DNA sequences among them. Our previous GISH results showed that $R$. coreanus had remote genetic relationship with $R$. tsangii and $R$. corchorifolius [55]. In this study, it seemed that $R$. parvifolius, rather than $R$. coreanus, had more close genetic relationship with these taxa in subg. Idaeobatus.

In the five tetraploids tested from subg. Malachobatus, GISH results also suggested that to whom it was $R$. parvifolius (R03-5) rather than $R$. coreanus (R03-6) that had much closer relationship with them. GISH signals showed that the common sequences with $R$. parvifolius concentrated not only at the telomere, but also at the centromere of four to fourteen chromosomes (Figures 3 and $4 \mathrm{~J}-\mathrm{N}$ ). When using $R$. coreanus DNA as a probe, only two signals at telomeric region were detected in tetraploid $R$. assamensis (R01-10) (Figures 3 and 4O). The variation in GISH signal intensity, produced by probes of $R$. parvifolius and $R$. coreanus (Figures 3 and 4), reflected the close relationship of these tetraploid species with $R$. parvifolius, yet distant with $R$. coreanus.

Rubus parvifolius was more genetically variable when compared with $R$. coreanus $[13,56]$. Extensive crossing and formation of natural hybrids with many species from both subgenera Idaoebatus and Malachobatus were found in $R$. parvifolius $[18,19,21-23]$. The fact that genomic DNA of $R$. parvifolius (R03-5) generated several common repetitive DNAs in polyploid species (Figures 3 and $4 \mathrm{~J}-\mathrm{O}$ ) here again highlighted the important role of $R$. parvifolius in hybridization, polyploidization and speciation of the two subgenera. Therefore it is likely just the crossability of such species as $R$. parvifolius that account for the gene flow or introgression in the genus.

\section{Conclusions}

In summary, the duplicated $45 \mathrm{~S}$ rDNA sites tend to be conserved, whereas those of $5 \mathrm{~S}$ rDNA tend to be eliminated after polyploidization in the genus Rubus. The signals from FISH indicated that the polyploids tested in this study are allopolyploid origin. Reciprocal GISH analysis between $R$. parvifolius and polyploids reveals diverse signal number and distribution patterns, and the important role of $R$. parvifolius in hybridization, polyploidization and speciation of the two subgenera is highlighted. However, there is not enough evidence revealing phylogenetic relationships between the subg. Idaeobatus diploid species and Malachobatus polyploid species in Rubus from this study. To further elucidate the phylogeny within Rubus, molecular data produced by multiple DNA sequences as well as morphological evidence with more species are necessary.

\section{Methods}

\section{Plant materials}

18 accessions from 9 sections of subgenera Idaeobatus and Malachobatus were used in this study (Table 1), 
including 14 Rubus taxa (9 diploids, 5 tetraploids and an octoploid) and 3 resembling $R$. parvifolius accessions (3 triploids). All plants were planted in the Teaching and Scientific Research Base of Sichuan Agricultural University. The voucher specimens were deposited in the herbarium of the College of Horticulture, Sichuan Agricultural University, China.

\section{Chromosome preparations}

Chromosome preparation was followed the procedures of Wang et al. [13]. Briefly, root tips from cutting propagation canes were pretreated in $0.002 \mathrm{~mol} \cdot \mathrm{L}^{-1} 8$ hydroxyquinoline at $4^{\circ} \mathrm{C}$ for $4 \mathrm{~h}$, and fixed in Carnoy's I solution (absolute ethanol : glacial acetic acid $=3: 1$, $\mathrm{v} / \mathrm{v})$ at $4^{\circ} \mathrm{C}$ for about $24 \mathrm{~h}$. The fixed root tips were hydrolyzed in $1 \mathrm{~mol} \cdot \mathrm{L}^{-1} \mathrm{HCl}$ at $60^{\circ} \mathrm{C}$ for $30-40 \mathrm{~s}$, stained with Carbol Fuchsin, and then squashed with $45 \%$ acetic acid. The chromosome slides with well-spread metaphases were frozen in liquid nitrogen for $5 \mathrm{~min}$. After removal of the coverslip, slides were air dried, and then kept at $-80^{\circ} \mathrm{C}$ until use.

\section{DNA extraction and probe preparation}

Total genomic DNA was isolated from $0.1 \mathrm{~g}$ unexpanded leaf tissue using a modified CTAB protocol [57]. 45S rDNA probe was labelled with biotin-16-dUTP using nick translation (Roche Applied Science, Mannheim, Germany) using primers 18S-F1 (5'-TAC CTG GTT GAT CCT GCC AGT A-3') and 18S-R1 (5'-CAA TGA TCC TTC CGC AGG TTC A-3') [58] with DNA template from $R$. coreanus. 5S rDNA probe was amplified and directly PCR-labelled by digoxigenin probe synthesis kit (Roche) with primers 5S1 (5'-GGA TGC GAT CAT ACC AG CAC-3') and 5S2 (5'-GGG AAT GCA ACA CGA GGA CT-3') [59].

For GISH, the genomic DNA were labelled by a nicktranslation reaction with digoxigenin-11-dUTP (Roche). $R$. parvifolius $(R 03-5 ; 2 x), R$. coreanus $(R 03-6 ; 2 x)$ and $R$. assamensis $(R 01-10$; 4x) DNA were used in GISH analysis (Figures 3, 4, 5 and 6).

\section{In situ hybridization}

In situ hybridization was performed with minor modifications of the procedure by Lim et al. [37]. Prior to hybridization, the chromosome slides were treated with an enzymatic mixture (2\% Cellulase and 2\% Pectinase, $\mathrm{w} / \mathrm{v}$, Sangon, China) at $37^{\circ} \mathrm{C}$ for $1.5 \mathrm{~h}$, followed by incubating in $100 \mu \mathrm{g} \cdot \mathrm{mL}^{-1}$ RNase A (Sigma-Aldrich, St Louis, MO, USA) solution (in $2 \times$ SSC, saline sodium citrate buffer) at $37^{\circ} \mathrm{C}$ for $1 \mathrm{~h}$. Afterwards, they were digested with $1 \mathrm{mg} \cdot \mathrm{mL}^{-1}$ Proteinase $\mathrm{K}$ (Sangon, China) at $37^{\circ} \mathrm{C}$ for $30 \mathrm{~min}$, fixed in $4 \%(\mathrm{w} / \mathrm{v})$ paraformaldehyde at room temperature (RT) for $10 \mathrm{~min}$, and dehydrated in an increasing series ethanol of $75 \%, 95 \%, 100 \%$ for $5 \mathrm{~min}$ each. The slides were denatured with $70 \%(\mathrm{v} / \mathrm{v})$ formamide in $2 \times \mathrm{SSC}$ at $70^{\circ} \mathrm{C}$ for $3 \mathrm{~min}$ and dehydrated immediately using an ice-cold ethanol series $(75 \%, 95 \%$ and $100 \%$ ) for $5 \mathrm{~min}$, respectively. The hybridization mixture contained $\sim 100$ ng labelled of probe, $2 \times \mathrm{SSC}, 50 \%(\mathrm{v} / \mathrm{v})$ formamide deionized, $10 \%(\mathrm{w} / \mathrm{v})$ dextran sulfate (DS), $0.1 \%(\mathrm{v} / \mathrm{v})$ sodium dodecyl sulfate (SDS) and $300 \mathrm{ng}$ sheared salmon sperm DNA or unlabelled blocking DNA. The ratio of blocking DNA to probe DNA was $0,50: 1$, or 100:1 in hybrid identification (Figures 5 and 6).

The hybridization mixture was denatured at $100^{\circ} \mathrm{C}$ for $5 \mathrm{~min}$ and placed instantly on ice for $10 \mathrm{~min} .30 \mu \mathrm{L}$ of the hybridization mixture was applied to each slide, and then hybridized overnight at $37^{\circ} \mathrm{C}$ in a humid chamber. The stringency conditions were decided by the concentration of formamide in hybridization mixture together with the condition of post-hybridization washing according to the calculations by Schwarzacher and Heslop-Harrison [60]. Post-hybridization washes were performed in $20 \%(\mathrm{v} / \mathrm{v})$ formamide (in $0.1 \times \mathrm{SSC})$ at $42^{\circ} \mathrm{C}$ for $10 \mathrm{~min}$, and $2 \times \mathrm{SSC}$ at RT for $5 \mathrm{~min}$, which resulted in a comparatively high stringency $(\sim 85 \%)$. Biotin-labelled and digoxigenin-labelled probes were detected with tetramethyl-rhodamine isothiocyanate (TRITC) (Thermo) and avidin-fluorescein isothiocyanate (FITC) (Roche) in $0.5 \%(w / v)$ BSA (bovine serum albumin) solution (in $1 \times \mathrm{PBS}$, phosphate buffer saline), respectively. The chromosome slides were counterstained with $2 \mathrm{ng} \cdot \mathrm{LL}^{-1}$ 4, 6-diamidino-2-phenylindole (DAPI, Sigma) in the VectaShield antifade solution (Vector Laboratories, Burlingame, California, USA).

The images were captured with a high-resolution cooled CCD camera using a fluorescence microscope (Olympus BX 51, Japan), and processed by Image ProPlus 6.0 (Openlab, Improvision, UK). A color composite image was merged by using the Color Composite feature with multiple fluorescent images acquired as monochrome single wavelengths. At least five mitotic metaphase complements per accession were scored. The karyotypes of FISH and GISH were referenced and followed our previous results as Wang et al. $[12,13]$. The cytological classification of somatic metaphase chromosomes follows the categories of Tanaka $[61,62]$.

\section{Abbreviations \\ DAPI: 4', 6-diamidino-2-phenylindole; DIG: Digoxigenin; FISH: Fluorescence in situ hybridization; FITC: Avidin-fluorescein isothiocyanate; GISH: Genomic in situ hybridization; rDNA: Ribosomal DNA; rRNA: Ribosomal RNA; TRITC: Tetramethyl-rhodamine isothiocyanate; PCR: Polymerase chain reaction.}

\section{Competing interests}

The authors declare that they have no competing interests.

\section{Authors' contributions}

YW and LZ collected the samples. YW performed the DNA extraction and production of probes and drafted the manuscript. QC and XRW supervised 
the experiments studies, helped draft the manuscript and revised the final text. HRT, YL, and ZJL contributed reagents and analysis tools. All authors read and approved the final manuscript.

\section{Acknowledgements}

The authors thank Dr. Andrew R. Leitch from Queen Mary University of London for helping revise this manuscript. This study was supported by the National Natural Science Foundation of China projects (No. 31272134 and 30971990)

\section{Received: 24 November 2014 Accepted: 21 January 2015}

\section{Published online: 03 February 2015}

\section{References}

1. Howarth DG, Gardner DE, Worden CW. Phylogeny of Rubus subgenus Idaeobatus (Rosaceae) and its implications toward colonization of the Hawaiian Islands. Syst Bot. 1997;22(3):433-41.

2. Focke WO. Species Ruborum. Bibliotheca Bot: Abhandlungen aus dem Gesammtgebiete der Botanik. 1910;17(72):1-120.

3. Focke WO. Species Ruborum. Bibliotheca Bot: Abhandlungen aus dem Gesammtgebiete der Botanik. 1911;17(72):121-223.

4. Focke WO. Species Ruborum. Bibliotheca Bot: Abhandlungen aus dem Gesammtgebiete der Botanik. 1914;19(83):224-488.

5. Jennings DL. Raspberries and blackberries: Their breeding, diseases and growth. London: Acad Press; 1988.

6. Thompson MM. Survey of chromosome numbers in Rubus (Rosaceae: Rosoideae). Ann Mo Bot Gard. 1997;84:128-64.

7. Iwatsubo Y, Naruhashi N, Weber H. Chromosome numbers of European blackberries (Rubus subg. Rubus, Rosaceae). Plant Syst Evol. 2005;198:143-9.

8. Lu LD. A study on the genus Rubus of China. J Syst Evol. 1983;21:13-25.

9. Yü DJ, Lu LD, Gu CZ, Guan KJ, Li CL. Flora Reipublicae Popularis Sinicae (Vol. 37). Beijing: Sci Press; 1985. p. 10-218.

10. Lu LD, Boufford DE. Rubus Linnaeus, Sp. P1. 1: 492. 1753. Flora China 2003;9:195-285.

11. Naruhashi N, Iwatsubo Y, Peng Cl. Chromosome numbers in Rubus (Rosaceae) of Taiwan. Bot Bull Acad Sinica. 2002;43:193-201.

12. Wang XR, Tang HR, Duan J, Li L. A comparative study on karyotypes of 28 taxa in Rubus sect. Idaeobatus and sect. Malachobatus (Rosaceae) from China. J Syst Evol. 2008:46:505-15.

13. Wang XR, Liu Y, Zhong BF, Dong XL, Chen Q, Xia WF, et al. Cytological and RAPD data revealed genetic relationships among nine selected populations of the wild bramble species Rubus parvifolius and $R$. coreanus (Rosaceae). Genet Resour Crop Evol. 2010;57:431-41.

14. Alice LA, Campbell CS. Phylogeny of Rubus (Rosaceae) based on nuclear ribosomal DNA internal transcribed spacer region sequences. Amer J Bot. 1999;86(1):81-97.

15. Alice LA, Dodson TM, Sutherland BL. Diversity and relationships of Bhutanese Rubus (Rosaceae). Acta Hortic. 2008;777:63-9.

16. Morden CW, Gardner DE, Weniger DA. Phylogeny and biogeography of Pacific Rubus subgenus Idaeobatus (Rosaceae) species: Investigating the origin of the endemic Hawaiian raspberry R. macraei. Pac Sci. 2003:57(2):181-97.

17. Yang JY, Pak JH. Phylogeny of Korean Rubus (Rosaceae) based on ITS (nrDNA) and trnL/F intergenic region (cpDNA). J Plant Biol. 2006;49(1):44-54.

18. Iwatsubo Y, Naruhashi N. Karyomorphological and cytogenetical studies of Rubus parvifolius, R. coreanus and $R . \times$ hiraseanus (Rosaceae). Cytologia. 1991:56:151-6.

19. Iwatsubo Y, Naruhashi N. Cytotaxonomical studies of Rubus (Rosaceae) I: Chromosome numbers of 20 species and 2 natural hybrids. J Jpn Bot. 1992;67:270-5

20. Iwatsubo Y, Naruhashi N. Cytotaxonomical studies of Rubus (Rosaceae) II: Chromosome numbers of 21 species and 6 natural hybrids. J Jpn Bot. 1993;68:159-65.

21. Iwatsubo Y, Naruhashi N. Cytogenetical studies of Rubus $\times$ tawadanus (Rosaceae). Cytologia. 1993:58:2175-221.

22. Iwatsubo $Y$, Naruhashi N. A comparative chromosome study of Rubus $X$ nikaii, R. parvifolius and R. phoenicolasius (Rosaceae). J Jpn Bot. 1996:71:333-7.

23. Iwatsubo $Y$, Naruhashi N. Cytogenetic studies of natural hybrid, Rubus $X$ hiraseanus, and artificial hybrid between $R$. coreanus and $R$. parvifolius (Rosaceae). Cytologia. 1998;63:235-8.
24. Li WL, Wu WL, Zhang ZD. The utilization value and potential of Chinese bramble (Rubus L.). Acta Hortic. 2001;585:133-8.

25. Chester M, Leitch AR, Soltis PS, Soltis DE. Review of the application of modern cytogenetic methods ( $\mathrm{FISH} / \mathrm{GISH}$ ) to the study of reticulation (polyploidy/hybridization). Genes. 2010;1:166-92.

26. Jiang J, Gill BS. Current status and the future of fluorescence in situ hybridization (FISH) in plant genome research. Genome. 2006;49:1057-68.

27. Raskina SN, Rani V. GISH technology in plant genome research. Meth Cell Sci. 2001;23:83-104.

28. Bammi RK. Cytogenetics of Rubus. IV. Pachytene morphology of Rubus parvifolius L. chromosome complement. Can J Genet Cytol. 1965;7:254-8.

29. Nybom H. Chromosome numbers and reproduction in Rubus subg. Malachobatus. Plant Syst Evol. 1986;152:211-8.

30. Thompson MM. Chromosome numbers of Rubus species at the national clonal germplasm repository. HortScience. 1995;30(7):1447-52.

31. Thompson MM. Chromosome numbers of Rubus cultivars at the national clonal germplasm repository. HortScience. 1995;30(7):1453-6.

32. Pool PA, Ingram R, Abbott RJ, Jennings DL, Topham PB. Karyotype variation in Rubus with particular reference to $R$. idaeus $L$. and $R$. coreanus Miquel. Cytologia. 1981;46:125-32.

33. Wang XR, Tang HR, Zhong BF, Xia WF, Liu Y. Karyotypic, palynological, and RAPD study on 12 taxa from two subsections of section Idaeobatus in Rubus $L$. and taxonomic treatments of $R$. ellipticus, $R$. pinfaensis, and $R$. ellipticus var. obcordatus. Plant Syst Evol. 2009;283:9-18.

34. Mishima M, Ohmido N, Fukui K, Yahara T. Trends in site-number change of rDNA loci during polyploid evolution in Sanguisorba (Rosaceae). Chromosoma. 2002;110:550-8.

35. Mezzetti B, Landi L, Phan BH, Taruschio L, Lim KY. Peg-mediated fusion of Rubus idaeus (raspberry) and $R$. fruticusus (blackberry) protoplasts, selection and characterization of callus lines. Plant Biosyst. 2001;135(1):63-9.

36. Lim KY, Hadonou AM, Knight VH, Bennett MD, Leitch IJ. The application of genome 'painting' in polyploidy Rubus. Acta Hortic. 1998;484:367-71.

37. Lim KY, Leitch IJ, Leitch AR. Genomic characterization and the detection of raspberry chromatin in polyploid Rubus. Theor Appl Genet. 1998;97(7):1027-33.

38. Wang $Y$, Chen $Q$, He W, Chen $T$, Nan H, Tang HR, et al. Genetic relationships between Rubus parvifolius and R. coreanus (Rosaceae), and preliminary identification one of their putative hybrids. Indian J Genet PI Br. 2013;73(1):72-81.

39. Roa F, Guerra M. Distribution of 455 rDNA sites in chromosomes of plants: Structural and evolutionary implications. BMC Evol Biol. 2012;12:225.

40. Ma Y, Islam-Faridi MN, Crane CF, Ji Y, Stelly DM, Price HJ, et al. In situ hybridization of ribosomal DNA to rose chromosomes. J Heredity. 1997;88:158-61.

41. Fernandez-Romero MD, Torres AM, Millan T, Cubero Jl, Cabrera A. Physical mapping of ribosomal DNA on several species of the subgenus Rosa. Theor Appl Genet. 2001;103:835-8.

42. Lim KY, Werlemark G, Matyasek R, Bringloe JB, Sieber V, Mokadem HE, et al. Evolutionary implications of permanent odd polyploidy in the stable sexual, pentaploid of Rosa canina L. Heredity. 2005;94:501-6.

43. Rho IR, Hwang YJ, Lee HI, Lee CE, Lim KB. Karyotype analysis using FISH (fluorescence in situ hybridization) in Fragaria. Sci Hortic. 2012;136:95-100.

44. Liu B, Davis TM. Conservation and loss of ribosomal RNA gene sites in diploid and polyploid Fragaria (Rosaceae). BMC Plant Biol. 2011;11:157.

45. Pikaard CS. The epigenetics of nucleolar dominance. Trends Genet. 2000;16:495-500.

46. Maghuly F, Schmoellorl B, Temsch EM, Laimer M. Genome size, karyotyping and FISH physical mapping of $45 \mathrm{~S}$ and $5 \mathrm{~S}$ genes in two cherry rootstocks: Prunus subhirtella and Prunus incisa $\times$ serrula. J Biotechnol. 2010;149:88-94.

47. Kraft T, Nybom H, Werlemark G. Rubus vestervicensis (Rosaceae)-its hybrid origin revealed by DNA fingerprinting. Nord J Bot. 1995;15:237-42.

48. Harlan JR, Oewet JMJ. On O. Winge and a prayer: The origins of polyploidy. Bot Rev. 1975;41(4):361-90.

49. Bretagnolle F, Thompson JD. Gametes with the somatic chromosome number: Mechanisms of their formation and role in the evolution of autopolyploid plants. New Phytol. 1995;129:1-22

50. Arnold ML. Natural hybridization as an evolutionary process. Annu Rev Ecol Evol and Syst. 1992;23:237-61.

51. Choi YA, Tao R, Yonemori K, Sugiura A. Multi-color genomic in situ hybridization identifies parental chromosomes in somatic hybrids of Diospyros kaki and D. glandulosa. Hort Sci. 2002;37(1):184-6. 
52. Kono Y, Chung MC, Peng Cl. Identification of genome constitutions in Begonia $\times$ chungii and its putative parents, B. longifolia and B. palmate, by genomic in situ hybridization (GISH). Plant Sci. 2012;185-186:156-60.

53. Soltis PS, Soltis DS. The role of hybridization in plant speciation. Annu Rev Plant Biol. 2009;60:561-88.

54. Raina SN, Mukai Y, Yamamoto N. In situ hybridization identifies the diploid progenitor species of Coffea arabica (Rubiaceae). Theor Appl Genet. 1998:97:1204-9.

55. Wang Y, Nan H, Chen Q, He W, Zhang L, Wang XR, et al: Genomic in situ hybridization analysis between Rubus coreanus and its relatives in Rubus (Sect. Idaeobatus). Plant Biosyst. 2014, doi:10.1080/11263504.2014.941030.

56. Wang XR, Tang HR, Huang L, He ZZ, Fu HQ, Deng QX: Comparative studies on pollen submicroscopic morphology of some wild species and cultivars of bramble (Rubus L.). Acta Hortic Sinica. 2007;34(6):1395-1404.

57. Zhou YQ. Application on DNA molecular markers technology in plant study. Beijing: Chem Ind Press; 2005

58. Zhang DM, Sang T. Physical mapping of ribosomal RNA genes in Peonies (Paeonia, Paeoniaceae) by fluorescent in situ hybridization: Implications for phylogeny and concerted evolution. Amer J Bot. 1999:86(5):735-40.

59. Fukui K, Kamisugi YK, Sakai T. Physical mapping of 5S rDNA loci by direct-cloned biotinylated probes in barley chromosomes. Genome. 1994;37:105-11.

60. Schwarzacher T, Heslop-Harrison JS. In situ hybridization. Oxford, UK: BIOS Scientific Publishers; 2000.

61. Tanaka R. Types of resting nuclei in Orchidaceae. Bot Maga Tokyo. 1971:84:118-22.

62. Tanaka R. Recent karyotype studies. In: Koike S, Kurosumi I, Sato M, Ogawa K, editors. Plant Cytol. Tokyo: Asakura Shoten; 1977. p. 293-326.

\section{Submit your next manuscript to BioMed Central and take full advantage of:}

- Convenient online submission

- Thorough peer review

- No space constraints or color figure charges

- Immediate publication on acceptance

- Inclusion in PubMed, CAS, Scopus and Google Scholar

- Research which is freely available for redistribution 